\title{
Towards a Pedagogy of Humanizing Child Education in Terms of Teacher-Student Interaction
}

\author{
Yi-Huang Shih ${ }^{1}$ \\ ${ }^{1}$ Department of Early Childhood Educare, Ching Kuo Institute of Management and Health, Keelung, Taiwan \\ Correspondence: Yi-Huang Shih, Department of Early Child Educare, Ching Kuo Institute of Management and \\ Health, Keelung, Taiwan. Tel: 886-2-2437-2093.
}

Received: January 7, 2018

Accepted: February 2, 2018 Online Published: March 20, 2018

doi:10.5539/jel.v7n3p197

URL: https://doi.org/10.5539/jel.v7n3p197

\begin{abstract}
By reading and analyzing related studies, this article investigates methods for humanizing child education in terms of teacher-student interaction. It is hoped that this study will allow teachers to understand the essence of child education, to become better educators and humanizing child education, so that students can develop a healthy body and mind and become better citizens in the future. The suggestions are as follows: (1) teachers' instruction must fit each child, (2) it must be understood that all children have their own talents, (3) there must be a connection with the child's real learning experiences, (4) teaching should pertain to the child's interest, (5) teachers must recognize the child's nature, (6) oppressive educative relationships between teachers and students must be eliminated, (7) children must be allowed to learn through their own experiences and discoveries and (8) teachers must think in a humanizing way.
\end{abstract}

Keywords: humanizing child education, the child, teacher-student interaction

\section{Introduction}

The most concerning thing in current society is not just the economic and social crisis, but also the spiritual emptiness, meaninglessness and hopelessness, which permeates the vast majority of society. There is a need for a new rational value system that is based on the humanization of man and society in general (Danica \& Sazhko, 2013). However, if man or society is to be humanized, the idea must be practiced through education. Several years ago, humanistic education developed as a reaction to exposure to detrimental or unhealthy environments in many classrooms (Patterson, 1987). In fact, while the problem of humanization has always been humankind's central problem, it has taken on the character of an inescapable concern. This concern for humanization leads to the recognition of dehumanization not only as an ontological possibility, but as an historical reality. As an individual perceives the extent of dehumanization, he or she may ask if humanization is a viable possibility. Throughout history, in concrete objective contexts, both humanization and dehumanization have been possibilities for an uncompleted being who is conscious of his or her incompletion (Freire, 2000). In other words, both humanization and dehumanization are possibilities in society. The educational field is a form of society, so humanization and dehumanization are also possibilities in education. However, humanizing education in a democratic society requires an adequate conception of democratic life (Soltics, 2013). In other words, the humanization of education must include elements of democracy. The essential elements of democracy include respect for human rights and fundamental freedoms and freedom of expression and opinion (United Nations High Commissioner for Human Rights, 2014). The principal concern is how to make man better and there is but one answer: education (Parker,1889). Education is important, because it has a significant influence on personal and social development. Teachers must understand the essence of education and have greater educational awareness, so that students can lead healthy and fulfilling lives. Children are a nation's most important asset and hope (Shih, 2013). Children need teachers' care and love, and teachers must respect children's rights and fundamental freedoms, freedom of expression and opinion to create a humanizing climate of learning. Therefore, the humanization of child education is necessary. Teachers and students both have important roles in classrooms, so this study investigates methods of humanizing child education, in terms of teacher-student interaction. It is hoped that this study will give teachers a greater understanding of the essence of child education to become better child educators and that child education will be humanized, so that students can develop a healthy body and mind and become better citizens in the future. 


\section{Methodology}

This article uses the documentary analysis method. In this kind of analysis, we explore various arguments or events by applying deductive and inductive logic (Wang, 1991). This article is based on the analysis of studies related to humanizing child education, and uses deductive and inductive logic to explore the practice of humanizing teaching methods for the child based on the interaction between teachers and students.

\section{The Importance of Humanizing Child Education}

Teachers and students share the main roles in education. In education, teachers and students are the protagonists. Teachers usually have experience with a variety of different students so it is important for teachers to know how to handle certain situations that are specific to students, especially when these involve behavioral problems. However, teachers must deal with behavioral problems among students in ways that are humanizing. In fact, humanizing child education relies on the pedagogy of educators to influence, navigate and coexist within the socio-political context and practices of teacher leaders, students, administration and community members (Law, 2015; Parker, 1969). Humanizing child education must fit each child and must address each child's specific needs and individual potentialities.

"A Nation at Risk," "No Child Left Behind" and "Race to the Top" have emerged familiar terminologies in the educational field in the United States, where students seem to struggle academically in many different ways. All of these initiatives have the declared intent to "fix" whatever is wrong with education. Unfortunately, the issues in this field are difficult to define and often become the center of heated debates and controversial proposals. Deciding which educational practices are best suited to the promotion of stronger academic performance is not easy. There are many approaches to education and infinite nuances within each approach. Many general approaches to supporting failing schools provide detailed, step-by-step, and prescriptive instruction. However, only a learner-centered, humanistic approach can provide an ideal learning environment for each student (Zucca-Scott, 2010).

\section{The Meaning of Teacher-Student Interaction}

The lens of humanizing education defines teaching as a process and a vision for life in schools and beyond -- not only for students, but also for ourselves (Price, 2014), and defines teaching as a unifying activity that involves interaction between teachers and students. For this reason, in order to develop the concept of humanizing child education, any study must reflect teacher-student interaction. Dynamic interactions between teachers and their students occur in school classrooms on a daily basis. Whether engaged in instruction or transitioning between activities, teachers and students have myriad opportunities to interact with each other. This has been the subject of numerous studies (Sandra, Eileen, Catherine, Mark, Allyson \& David, 2013).

Past attempts to define and measure quality in childhood education have yielded limited results. It is known that many of the more commonly debated regulations that are intended to improve the quality of classrooms (i.e., class size, teacher education and credentialing) are not sufficient to ensure that children make academic and social progress. Similarly, the implementation of different curricula has done little to improve student achievement, because it is teachers' facilitation of learning objectives, and not simply having the curriculum box on the shelf, that determines whether children benefit from instruction. Consistent evidence suggests that if children's academic achievement is to be improved and their social skills developed, there must be a focus on how teachers instruct and relate with children (Pianta, 2010).

When effective interactions are identified and measured, opportunities are created to promote them through teacher education, professional development and the curriculum and evaluation. Teachers also increase their competency, become more effective teachers, experience greater job satisfaction and remain in the field of teaching. Most importantly, more effective teacher-student interactions and improved teacher outcomes lead to enhanced outcomes for children: children learn more and develop the social skills that are necessary for future achievement (Pianta, 2010). Teachers must be the will of the child until the child achieves the age of reason, or has knowledge of right and wrong, and encourage good habits, or the child's own unreasoning desire will govern the will from the outset (Parker, 1896).

In brief, all children are individuals who are unique in their abilities and who come from a rich diversity of backgrounds, beliefs and cultures. Children have the right to be treated with respect, positive regard and dignity. Children should be enabled to acknowledge, respect and affirm diversity, in order to promote equality and to challenge unfair discrimination. Warm, humanizing relationships support children's development in this regard, so humanizing teacher-student interaction is important for all students. 


\section{Some Suggestions for Developing Humanizing Child Education in Terms of Teacher-Student Interaction}

By reading and analyzing related studies (Ayres, 1993; Brandenberger, 2017; Cíntia Santana e Silva \& Bruno Lazzarotti Diniz Costa, 2016; Harris, 1898; Hohmann \& Weikart, 1995; Katz, 2017; Huang, 2015; Kilpatrick, 1914; Law, 2015; Parker \& Helm, 1898; Parker, 1969; Straughan, 1982; Walsh, 2008; Zucca-Scott, 2010), some suggestions for developing humanizing child education in terms of teacher-student interaction are given as follows.

\subsection{Teachers' Teaching Must Fit Each Child}

The idea that education should consider different students' abilities is an important part of the educational thought of Confucius. "Confucius believed that a child's level of education should be attuned to his level of intellectual and physical development". In addition, Confucius' pedagogy for motivating his students to learn was to consider which ability the student was lacking and then motivate him to acquire it (Lai, 2000). In fact, each student is unique in his or her strengths and challenges and it is the job of the teacher to foster highly individualized learning in response to the student (Brandenberger, 2017). The child is also a body that grows and a soul that develops. If any educational act is to be efficacious, it will be only that which tends to aid the complete unfolding of the child's individuality (Kilpatrick, 1914). Teachers' teaching must fit each child and be in line with his or her specific needs and learning interests. The construction of beliefs and practices around a humanizing education focuses on the cultural, historical and contextual realities and experiences of the learner. Each child is born an artist. The problem is allowing the child to remain an artist when he/she grows up (Law, 2015; Parker, 1969).

\subsection{Trust That All Students Have Their Own Talents}

Educational quality is strongly intertwined with creating opportunities for all students to be themselves. Schools must help students to discover who they are and what their talents are as individuals. All students have talents, but they do not always have the opportunity to express those talents (Zucca-Scott, 2010). Teachers must trust that all students have their own talents, and make opportunities for students to express their talents so that children can be themselves. Teachers can encourage and help the child to develop a unique pattern of talents (Hohmann \& Weikart, 1995).

\subsection{In Connection with the Child's Real Learning Experiences}

It is, of course, to be borne in mind that a child's experience is vastly different from the adult experience (Kilpatrick, 1914, p. 65). The Pestalozzian movement in the history of education is justly famed for its effort to connect in a proper manner the daily experience of the child with the school of course of study. The branches of learning taught to the child by the schoolmaster are necessarily dry and juiceless if they are not thus bought into relation with the child's world of experience (Harris, 1898, pp. v-vi). Therefore, in connection with the child's real learning experiences is important.

\subsection{Teachers' Teaching Should Be Concerned with the Child's Interest}

No one who studies children can fail to notice the variety, the breadth, or the intensity of children's interests, which spring from instincts, the realization of which means life, growth, and character (Parker \& Helm, 1898). When the child interacts with materials, people, ideas and events to construct his/her own understanding of reality, teachers observe and interact with the child to discover how each child thinks and reasons. Teachers strive to recognize each child's particular interests and to offer the child-appropriate support and challenges (Hohmann \& Weikart, 1995).

A child's great need is for full and complete recognition on the part of parents and teachers of the immense value of spontaneous activities, as displayed in motive and interest (Parker, \& Helm, 1898, p. xi). Interest is important to the learning of children, so teachers should be concerned with the child's interest in the learning process.

\subsection{Teachers Must Know the Child's Nature}

Most teachers want to know more about their students and to know what engages and interests them (Ayres, 1993). Teachers must know the child and their heart must lie close to the child's heart (Parker, 1896, p. 169). In this way, teachers can understand the child's nature (Parker, 1896). For example, play is natural for most children and play life fosters the germs that go to strengthen a life of future, usefulness and happiness (Parker \& Helm, 1898), so teachers can incorporate play into their teaching, depending on the child's nature. 


\subsection{Eliminating the Oppressive Educative Relationships Between Teachers and Students}

Discussing violence in the school context implies that the school is a social space, a place of social interaction and the creation of ethos. It is necessary to observe the dynamics of daily interactions in the school, overcoming the notion that this institution is only a place for the theoretical learning of subjects that compose the school curriculum. The school environment is not restricted to learning of content, but is also an environment of appropriation and development of meanings and interpretations of the world and of life itself. Students and teachers are socio-cultural beings who are involved in daily interactions that determine, in large part, the attitudes within institutions, norms and the contents that are transmitted (Cíntia Santana e Silva \& Bruno Lazzarotti Diniz Costa, 2016).

Traditional education separates, or tries to separate, the child from himself or herself; it ignores the power that is gained by play, work and observation. It depreciates the best and fruitlessly strives to build without foundations (Parker, \& Helm, 1898, pp. x-xi). Dewey's clarification of the difference between training and education is explored for the impact that training-based schooling can have on educating for democracy. Freire's description of schooling is practiced through the banking-method of education. Both Dewey's and Freire's work show the potential discourse-related problems that are associated with educating for democracy. For example, Dewey notes how language can be used to train, rather than to educate, while Freire describes how language can be used didactically, rather than dialogically, to maintain oppressive educative relationships (Walsh, 2008). Education must be democratic and dialogical. Freire emphasizes the importance of dialogue between teachers and students. Through authentic dialogue, oppressive educative relationships between teachers and students can be eliminated and the humanizing of child education can begin. Therefore, teachers must eliminate the oppressive educative relationships between teachers and students.

\subsection{Let Children Learn Trough Their Own Experiences and Discoveries}

Given that children learn through their own experiences and discoveries, the role of teachers in the active learning environment is to promote interest. In the broadest sense, teachers are supporters of development and as such, their primary goal is to encourage active learning on the part of the child. Teachers do not tell children what to learn or how to learn it; instead, they empower children to take control of their own learning. In carrying out this role, teachers are not only active and participatory, but also observational and reflective; they are conscious participant-observers. If children learn through their own experiences and discoveries, children's thinking is extended (Hohmann \& Weikart, 1995). Therefore, teachers should let children learn through their own experiences and discoveries.

\subsection{Teachers Must Think in a Humanizing Way}

Dehumanization is arguably most often observed in relation to ethnicity, race and related topics, such as immigration and genocide. It is in this paradigmatic context of intergroup conflict that some groups are claimed to dehumanize others, and these dehumanizing images have been widely investigated (Haslam, 2006). In classrooms, there are some dehumanizing phenomena. Dehumanization is a complex, relational and subjective phenomenon. It is necessary to think in a humanizing way when a variety of things are encountered. Behaviorists assert that better instructional methods and suitable reinforcement strategies are required. However, from the social constructivist view of teaching and learning, students must co-construct calendar concepts with the children or let children "discover" these concepts for themselves (Katz, 2017). Whether the teacher is a constructor or behaviorist, teachers must think in a humanizing way. When teachers can think in a humanizing way, they can deal with students' behavior in a humanizing way. A teacher's thinking is a habit and a strategic process for collecting information, reflecting, understanding, solving problems, making decisions, initiating action and accumulating practical wisdom. The habit of a teacher's thinking can be cultivated during pre-service teacher education and be continued during the induction phase and during in-service teacher education (Huang, 2015).

\section{Conclusion}

The student must be viewed as a valued asset and active member of the learning process. The opposing pedagogy supports the standardization, mechanization and one-size-fits-all model that emphasizes quantification, measurement and high-stakes accountability for teachers and students (Law, 2015). In a society that is undergoing rapid technological development and an increasingly international economy, it is never clear how to prepare the child for future needs in a way that fosters their future well-being. Related to this endeavor, pre-service teacher education must be designed to prepare teachers to adapt to the changing environment and to continually upgrade their teaching practices. The characteristics of the ideal teacher that will be needed in the future must be carefully considered. Ideal teachers must ensure their own continued employability, increase 
their professional knowledge and skills and increase their ability to be developed by undertaking ongoing professional development that meets the future, as yet unknown needs of their students. Teachers must commit themselves to the continuous development of their teaching skills (Huang, 2015). In addition to teaching skills, teachers must also teach children in a humanizing way.

Each child has the power to succeed in school and in life and every teacher can help. The question is how to help children to succeed in school. The answer comes from a combination of common sense and research as to how children learn and how teachers can prepare them to learn in school (U.S. Department of Education, 2005). Most importantly, teachers must practice humanizing teaching. However, when teachers practice humanizing teaching, the teaching must fit each child and teachers must trust that all children have their own talents. Teachers must also connect with the child's real learning experiences when they teach. Thirdly, teachers' teaching should be concerned with the child's interest and teachers must know the child's nature. Eliminating the oppressive educative relationships between teachers and students and allowing children to learn through their own experiences and discoveries is vital. Teachers must think in a humanizing way, in order to promote pedagogy of humanizing child education in terms of teacher-student interaction.

\section{Acknowledgements}

This research was sponsored by the Ministry of Science and Technology, Taiwan [grant number 101-2410-H-254-001- \& 104-2410-H-254-001-].

\section{References}

A Focus on Humanizing Education. (2017). The teacher. Retrieved from http://www.gcrao.com/index.php?option=com_content\&view=article\&id=12\&Itemid=27

Aslam, F. (2016). Towards a humanising pedagogy through an engagement with the social-subjective in educational theorising in South Africa. Educational Research for Social Change, 5(1), 10-21. http://doi.org/10.17159/2221-4070/2016/v5i1a1

Ayres, W. (1993). To teach: The journey of a teacher. New York, NY: Teachers College Press.

Brandenberger, E. (2017). Daily edventure. Retrieved from http://dailyedventures.com/index.php/2014/08/18/ellenbrandenberger/

Center for Advanced Study of Teaching and Learning. (2017). Measuring and improving teacher-student interactions in PK-12 settings to enhance students' learning. Charlottesville, VA: Center for Advanced Study of Teaching and Learning.

Cíntia, S. E. S., \& Bruno, L. D. C. (2016). Oppression in schools: Bullying among students in basic education. Cadernos de Pesquisa, 46(161), 1-11.

Craft, A. (2010). Creativity and education futures: Learning in a digital age. Stoke-on-Trent, UK: Trentham Books.

Danica, P., \& Sazhko, G. (2013). Humanizing of higher education in Ukraine: Kraine blending of hard core sciences and humanities. Retrieved from http://www.trend.uns.ac.rs/stskup/trend_2013/radovi/T5.2/T5.2-1.pdf

Freire, P. (2000). Pedagogy of the oppressed. New York, NY: The Continuum.

Harris, W. T. (1898). Preface by the editor of home-reading books. In F. W. Parker \& N. L. Helm (Eds.), On the farm (pp. v-viii). New York, NY: D. Appleton and Company.

Haslam, N. (2006). Dehumanization: An integrative review. Personality and Social Psychology Review, 10, 252-264. https://doi.org/10.1207/s15327957pspr1003_4

Hohmann, M., \& Weikart, D. P. (1995). Educating young children: Active learning practices for preschool and child care programs. Ypsilanti, MI: The High/Scope Press.

Huang, J. L. (2015). Cultivating teacher thinking: Ideas and practice. Educational Research for Policy and Practice, 14(3), 247-257. https://doi.org/10.1007/s10671-015-9184-1

Katz, L. G. (2017). Child development knowledge and teachers of young children. Retrieved from file://C:/Users/User/AppData/Local/Microsoft/Windows/INetCache/IE/BO90KJ1D/childdev.pdf

Kilpatrick, W. H. (1914). The Montessori system examined. Boston: Houghton Mifflin. 
Lai, P. H. (2000). Taiwanese kindergarten teachers' and principals' beliefs and attitudes concerning developmentally appropriate art education (Unpublished doctoral dissertation). Iowa State University, Iowa.

Law, L. P. (2015). Humanizing education: Teacher leaders influencing pedagogical Change (Unpublished doctoral dissertation). Iowa State University, Iowa.

Parker, F. W. (1889). How to study geography. Bristol, UK: Thoemmes.

Parker, F. W. (1896). Talks on teaching. New York, NY: E. L. Kellogg \& co.

Parker, F. W. (1969). Talks on pedagogics. New York, NY: Arno Press.

Parker, F. W., \& Helm, N. L. (1898). On the farm. New York, NY: D. Appleton \& Co.

Patterson, C. H. (1987). What has happened to humanistic education. Michigan Journal of Counseling and Development, XVIII(1), 8-10.

Pianta, R. C. (2010). Effective teacher-student interactions: Measuring and improving classroom practice. New York, NY: Foundation for Child Development.

Price, J. N. (2014). Challenges of forging a humanizing pedagogy in teacher education. Retrieved from http://faculty.education.illinois.edu/m-osbor/osborne/hum.rtf

Shih, Y. H. (2014). A study on children industry in low birth rate trend in Taiwan. Journal of Ching Kuo Institute of Management and Health, 30, 37-50.

Soltics, J. F. (1991). Humanizing education: Dewey's concepts of a democratic society and purpose in education revisited. Studies in Philosophy and Education, 11, 89-92. https://doi.org/10.1007/BF00368406

The Education Trust. (2012). Building and sustaining talent: Creating conditions in high-poverty schools that support effective teaching and learning. New York, NY: The Education Trust.

U.S. Department of Education. (2005). Helping your child succeed in school. Washington, DC: U.S. Department of Education.

United Nations High Commissioner for Human Rights. (2014). Interdependence between democracy and human rights.

from

http://www.unhchr.ch/huridocda/huridoca.nsf/(Symbol)/E.CN.4.RES.2003.36.En?Opendocument

Walsh, J. (2008). The critical role of discourse in education for democracy. Journal for Critical Education Policy Studies, 6(2), 54-76.

Wang, W. K. (1991). Educational research methods. Taipei, Taiwan: Wu-Nan Book.

Zucca-Scott, L. (2010). Know thyself: The importance of humanism in education. International Education, 40(1), 31-38.

\section{Copyrights}

Copyright for this article is retained by the author(s), with first publication rights granted to the journal.

This is an open-access article distributed under the terms and conditions of the Creative Commons Attribution license (http://creativecommons.org/licenses/by/4.0/). 